\title{
Buffer zones maximize invertebrate conservation in a Biosphere Reserve
}

\author{
Colin S. Schoeman ${ }^{1}\left[\right.$ D Stefan H. Foord ${ }^{1}$
}

Received: 16 November 2020 / Accepted: 27 May 2021

(c) The Author(s), under exclusive licence to Springer Nature Switzerland AG 2021

\begin{abstract}
Recent declines in invertebrates are linked to anthropogenic global change drivers thus land use planning that considers invertebrate conservation is necessary. Although most animals are invertebrates, conservation initiatives largely ignore these groups in part because of a paucity of studies addressing their diversity patterns. Biosphere Reserves provide an holistic approach to conservation planning. Here we explore the covariates that underlie beetle and spider diversity across the largest Biosphere Reserve in South Africa and use this model to predict compositional turnover across the reserve using Generalized Dissimilarity Modelling (GDM). We then use these patterns to assess the proportion of the ecological environments, scaled using beetle and spider assemblages, that is included in either core or buffer zones. The GDM model explained 53\% of the variation in observed compositional turnover. Important local-scale drivers of turnover were leaf litter and organic content of the soil, while broad-scale co-variables were isothermality and mean diurnal range. Buffer zones increased conservation coverage by between 50 and $100 \%$, depending on the planning scenario involved and complimented regional conservation plans. However, local conservation practices rarely reflect that of regional planning exercises, and initiatives should focus on monitoring compliance that considers both landscape and local processes.

Implications for insect conservation Conservation efforts should not only focus on core areas in Biosphere Reserves. Managing buffer zones must receive similar if not more attention due to the larger anthropogenic footprint.
\end{abstract}

Keywords Epigeic $\cdot$ Coleoptera $\cdot$ Araneae $\cdot$ Vhembe Biosphere Reserve $\cdot$ Bioregions $\cdot$ Limpopo

\section{Introduction}

Humans are precipitating the 6th mass extinction on earth (Bellard et al. 2012; Díaz et al. 2020) and the global biodiversity crisis is one of the most pervasive concerns of contemporary life. Concerns have mostly centred around habitat loss, plant and vertebrate extinctions, and often ignores invertebrates (Samways et al. 2010). However, observed declines of invertebrates is a well-documented phenomenon (Leather 2017; Sánchez-Bayo and Wyckhuys 2019; Cardoso et al. 2020) with severe declines recorded for flying insects in Germany (Hallmann et al. 2017) and even for common and widely distributed moths in Britain (Fox 2013).

Colin S. Schoeman

Colin.Schoeman@gmail.com

1 Department of Zoology and Chair in Biodiversity Value and Change, Faculty of Science, Engineering and Agriculture, University of Venda, Thohoyandou, South Africa
A predicted invertebrate Armageddon calls for conservation initiatives that adequately consider the impacts of habitat loss, destruction and homogenization on biodiversity (Samways et al. 2020).

The current biodiversity crisis calls for the establishment of more protected areas (Kremen and Merenlender 2018), while mapped biodiversity provides the framework on which effective conservation plans are developed. This is mostly done using surrogates such as mammals, birds, and plants (Ferrier et al. 2004; Mittermeier et al. 2011). However, invertebrate diversity patterns do not always mirror well-known, and taxonomically well-defined groups (Oliver et al. 1998; Su et al. 2004; Schoeman et al. 2019a) and better results are obtained when several more taxa are included (Sauberer et al. 2004). Furthermore, invertebrate turnover occurs at smaller scales while mapping based on a largescale, coarse filter data might not predict insect diversity across space ( $\mathrm{Su}$ et al. 2004). Identifying covariates that vary with invertebrate $\alpha$-diversity and $\beta$-diversity across landscapes is therefore essential (Gering and Crist 2002). 
This would allow for predictions across both space and time. Alpha-diversity helps to identify hotspots (Mittermeier et al. 2011) but compositional turnover captures complimentarity between assemblages and is probably much more appropriate for conservation efforts at regional scales (Reyers et al. 2000; Kati et al. 2004).

Although reserves promote strict protection, edge effects can threaten biodiversity within areas of conservation (Woodroffe and Ginsberg 1998). The severity of edge effects depend however on the size of the conservation area, and must take into consideration other factors such as location and management (Constant and Bell 2017). Strict reserves should as a precaution be complemented with protected areas outside them (Gove et al. 2005). Biosphere reserves promote this holistic approach by circumscribing areas within them as core, buffer, and transitional zones (Ishwaran et al. 2008). Core areas comprise strictly protected reserves; buffer zones surrounding the core areas are important conservation areas but might not be formally designated as reserves; transition zones are areas of sustainable ecological practices and include human habitation.

In terms of diversity, epigeal fauna is often dominated by ground-dwelling beetles and spiders. Beetles are particularly species rich and locally abundant. The bulk of epigeal beetle diversity in Africa consists of three taxa, Carabidae, Tenebrionidae, and Scarabaeinae. Carabids are important predators of arthropods, with a few important seed feeders in the Harpalinae and Chlaeniinae. Over 960 species of Carabidae are known to occur in South Africa (Picker et al. 2004). Tenebrionidae and Scarabaeinae are significant detritivores, with the latter specializing on the dung of large herbivores (Picker et al. 2004). In fact, beetles can be regarded as biodiversity surrogates (Gerlach et al. 2013). Hutcheson (1990) considered them to be representative of insect diversity in general, as they include widespread and specialized species. They are rarely used however because of the taxonomic challenge of identifying them to genus and species, with only a few well-known beetle taxa used regularly, such as Scarabaeinae and Cicindelinae. Spiders can also act as surrogates (Sauberer et al. 2004; Foord and Dippenaar-Schoeman, 2016), because they are major predators of other invertebrates (Dippenaar-Schoeman et al. 2012) and consume an estimated 400-800 million tons of insect prey annually (Nyffeler and Birkhofer 2017). More than 2200 spider species are known from South Africa (DippenaarSchoeman 2014), and $>90 \%$ of all endemic spiders in South Africa are epigeic (Foord et al. 2020).

Overall, temperature and rainfall are the most significant predictors of biodiversity (Gaston 2000). However, local variation in climate and other environmental features such as vegetation cover, rocks, leaf litter, and the soil associated with microhabitats might also be important (Gough et al. 1994; Schoeman and Samways 2011; Gaigher and Samways
2014). These predictors often act as 'drivers' of diversity, not only local or alpha diversity, but also compositional change or beta diversity (Koleff et al. 2003). Large-scale selection of conservation units has been found to be remarkably effective in conserving regional biodiversity (Rouget 2003; Schaffers et al. 2008; Ramos et al. 2018). However, species may be distributed in patches, and preserving only part of a vegetation unit may miss an important component of the unit's species. Coarse-scale conservation strategies should be complemented with fine-scale data on patterns of invertebrate diversity (Lombard et al. 2003; Barton et al. 2011).

There are at present 714 biosphere reserves in 129 countries, including 21 transboundary sites (UNESCO 2021). Africa accomplishes 85 biosphere reserves and is the continent with the fewest. (Ten new biosphere reserves have been proclaimed since 2017.) Furthermore, very few studies measuring the effectiveness of core and buffer zones in protecting invertebrate biodiversity within biosphere reserves in Africa are available (but see Van Schalkwyk et al. 2019). Herein we use a dataset of epigeal spiders and beetles collected across the largest Biosphere Reserve in South Africa and ask the following questions. What are the relative roles of fine and large-scale variables in predicting invertebrate diversity? Furthermore, can we use these scaled environmental variables to predict richness and turnover across the Biosphere Reserve and evaluate the effectiveness of buffer and core zones in conserving two major groups of invertebrates?

\section{Methods and materials}

\section{Study site}

The Vhembe Biosphere Reserve (VBR) was inscribed in 2009 (Pool-Stanvliet 2013). It is situated in the northernmost region of Limpopo Province of South Africa (coordinates: $22^{\circ} 49^{\prime} 31.5^{\prime \prime} \mathrm{S} 29^{\circ} 53^{\prime} 46.5^{\prime \prime}$ E). 3037590 ha encompassing a diverse array of biomes and habitats, including mist-belt forest, mountainous flora, arid bushveld and moist savanna (Mucina and Rutherford 2006). The Soutpansberg mountains are the dominant geographic feature of the VBR and drives much of its environmental variation (Fig. 1, Appendix 1a). The VBR also contains important rivers and catchment areas, including the Limpopo and Luvuvhu Rivers (Modiba et al. 2017). The region has been identified as a centre for plant endemism (Hahn 2017), and several recent studies have highlighted the significance of its invertebrate diversity (Foord et al. 2002; Schönhofer 2008; Haddad 2009; Foord et al. 2015; Munyai and Foord 2015) with more than 700 spider species (Foord et al. 2002; Foord et al. 2019). A Strategic Environmental Management Plan (SEMP) was 


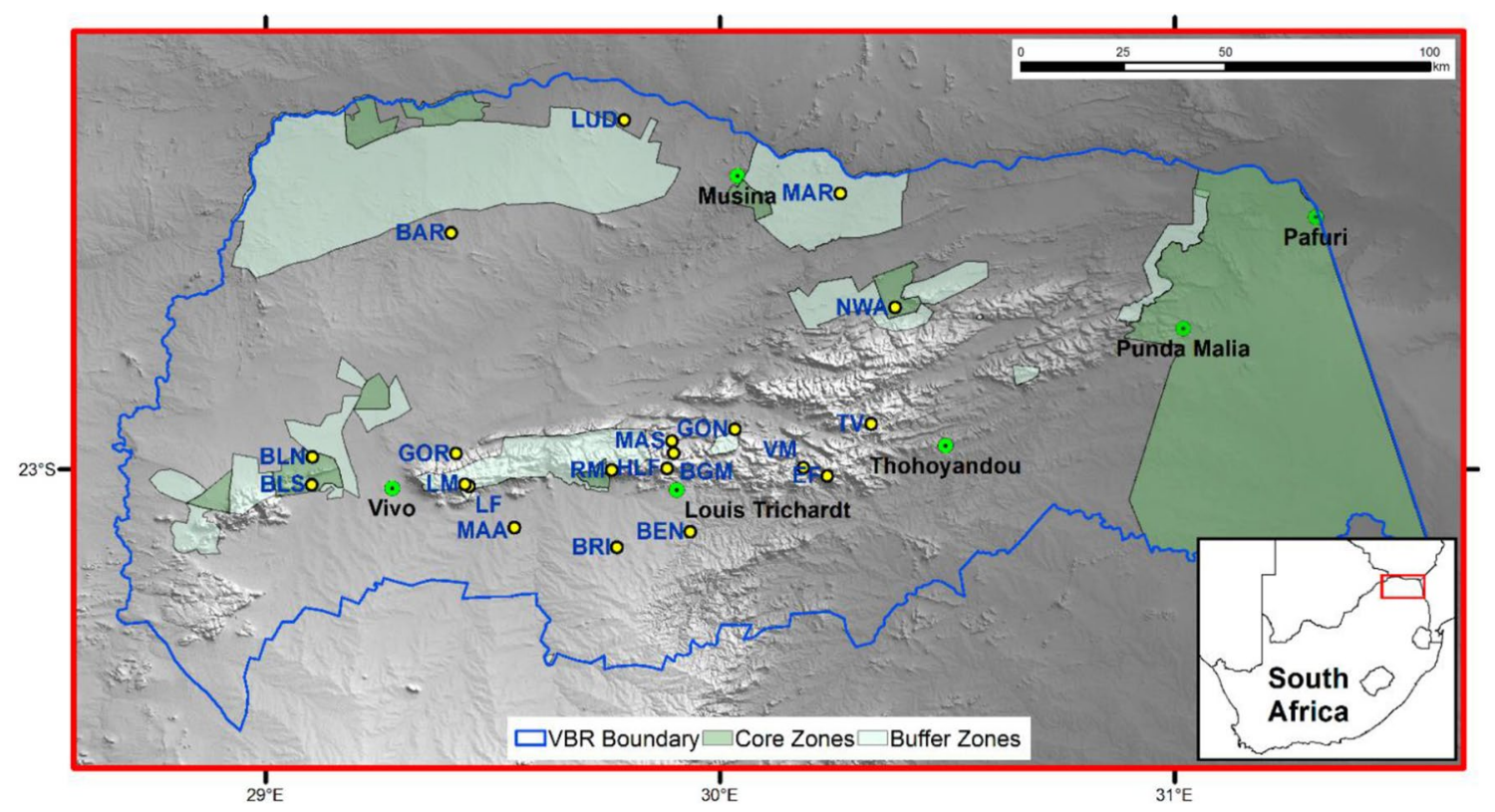

Fig. 1 Map of the Vhembe Biosphere Reserve showing distribution of existing core, buffer zones and transition areas; current core areas in dark green and buffer zones in lighter green, and outline of the reserve in blue. Yellow dots represent site localities. The remainder of the grey area outlined in blue is transition area. (Color figure online)

sites within the transition zones. Elevation, precipitation and temperature interact to produce distinct vegetation types in the region. These vegetation units occur in longitudinal eastto-west bands across the Biosphere Reserve (Appendix 1b). The Polokwane Plain and Eastern Limpopo Flats harbour geographically large, and continuous plant communities. We stratified 20 sampling sites across the major vegetation units (Mucina and Rutherford 2006) and longitudinal extent that the vegetation type covers in the Biosphere Reserve (Fig. 1). These were: Makhado Sweet Bushveld (3 sites), Soutpansberg Summit Sourveld (4 sites), Northern Mistbelt Forest (4 sites), Roodeberg Bushveld (2 sites), Soutpansberg Mountain Bushveld (4 sites), Musina Mopane Bushveld (2 sites), and Limpopo Ridge Bushveld (1 site). In each site, eight sampling units were selected. Sampling units were selected to be as representative of the vegetation unit as possible. Sampling effort was focussed on least anthropogenically disturbed habitats. Sampling units were a minimum of $300 \mathrm{~m}$ apart to avoid pseudoreplication (Samways et al., 2010). A sampling unit consisted of five pitfalls $(\varnothing=100$ $\mathrm{mm}$, height $=150 \mathrm{~mm}$ ), arranged in a pentagon spaced $10 \mathrm{~m}$ apart and filled with $100 \mathrm{ml}$ propylene glycol. The pitfalls of each SU were too close to each other to be considered independent and were therefore pooled in the analysis. The unit for data analysis is therefore the SU, for a total of eight SU's per site $\cdot 20$ sites $=160$ assemblages. The following small-scale environmental variables were collected at each sampling unit: leaf litter cover, vegetation complexity, organic content of soil and canopy cover. The $1 \mathrm{~m}^{2}$ area 
around each pitfall was imaged and the following variables estimated as such: percentage leaf litter cover; canopy cover (estimated from shade); habitat complexity (scored from 1 (bare ground), 2 (grass cover), 3 (grass cover, and small bushes), 4 (grass cover, large bushes) to 5 (thicket, forest); organic content was estimated from substrate or soil type (scored as 0: gravel, 1: sand 2: loam, 3: clay, 4: mulch).

Sampling was conducted in November-December 2012. This period corresponds with the start of the wet and hot summer period. Pitfalls were left open for seven days, contents were washed in the laboratory using a micro net and clean water and stored in $96 \%$ ethanol. Spiders were identified to species or morpho-species. Tenebrionidae and Carabidae were identified to species and Scarabaeidae to species and morphospecies. Spider specimens were deposited in the National Collection of Arachnida (NCA) of the Plant Protection Research Institute, Agricultural Research Council, Pretoria while beetle specimens were deposited in the Ditsong National Museum of Natural History and the University of Venda Sarchi Chair Biodiversity Collection.

\section{Data analysis}

Catches from a sampling unit were pooled resulting in eight assemblages per site $\times 20$ sites $=160$ assemblages. Sample coverage (Chao and Jost 2012) was calculated for observed richness at each sampling unit using the function 'iNEXT' in the iNEXT package (Sieh et al. 2014). Gridded climatic (Fick and Hijmans 2017) and land cover (Tuanmu and Jetz 2014) data at a resolution of $1 \mathrm{~km}^{2}$ were used to derive covariates at point localities. As there is considerable topographic variation in the VBR, slope, aspect (north-to-south and east-to-west orientation) and the Topographic Position Index were also calculated using Digital Elevation Models for the region. Models also included small-scale variables measured at each sampling unit. Colinearity between these predictors were explored using variance inflation factors (VIF). Variables that had VIF $>3$ were excluded from the analysis. Collinearity was further explored using Pearson product moment correlations between predictors.

Observed richness were modelled using Generalized Linear Mixed Models (GLMM) with a loglink function and Poisson error distribution using the function 'Imer' in the lmer package (De Boeck et al. 2011). Fixed factors included both broadscale climatic and landcover variables as well as finer scale predictors measured at each sampling unit. Site was included as a random factor to account for spatial autocorrelation between replicates within a site. Variograms of the residuals of the GLMM's were used to identify any spatial correlation between sites. Prior weights were given to observed richness variables based on their coverage. Better estimates of richness therefore contributed more to the model construction. Models were compared using the Akaike information criterion and the best models those that had $\triangle \mathrm{AIC}<2$ compared to the model with the lowest AIC (Burnham and Anderson 2004). Marginal $R^{2}\left(R^{2} m\right.$, due to fixed effects only) and conditional $R^{2}\left(R^{2} c\right.$, due to fixed and random effects) were calculated for the best model to determine how much of the variation is explained by fixed and random effects respectively (Nakagawa and Schielzeth 2010).

The compositional similarity was modelled using generalized dissimilarity models (GDM) at a resolution of 1 and $10 \mathrm{~km}^{2}$ across the VBR. GDM extends the traditional distance approach of matrix regression to include nonlinear relationships as well as flexible splines and a GLM that deals with two kinds of nonlinearity common in ecological data (Ferrier et al. 2007). It allows for the quantification of varying compositional turnover along a gradient. Patterns in turnover can be analysed as well as how different sites are in terms of environmental and geographic variables. The function ' $\mathrm{gdm}$ ' in the package gdm was used to fit generalized dissimilarity models based on Bray-Curtis dissimilarities, after biological and predictor data have been formatted to a site-pair table (Fitzpatrick and Lisk 2016) in R (R core team 2021). Each assemblage in the model was weighted sample coverage for that assemblage (Mammola et al. 2019). Spline heights represent the total biological change along that gradient, and relative importance of that predictor in contributing to biological turnover while holding all other variables constant (partial ecological distance). Variable importance were quantified using matrix permutation that tests the variable and model significance and estimate variable importance. Fifty permutations were done to estimate p-values (Ferrier et al. 2007). Output of the GDM model was used to predict compositional turnover across the VBR.

The proportional representation of ecological environments (scaled using spider and beetle data) in core and buffer zones, and the proportional sampling of these environments by the database were quantified as a continuous fraction of the entire biosphere reserve (Pennifold et al. 2017). We also assessed this representation for the Critical Biodiversity Areas 1 and CBA 2 used for regional conservation planning by the Limpopo Department of Economic Development, Environment and Tourism (Desmet et al. 2013). K-means clustering based on pair-wise Manhattan distances was used to identify regions that are largely homogenous in species composition, and the optimum number of groups was chosen by using the silhouette coefficient (Kaufman and Rousseeuw 2009). 


\section{Results}

A total of 2624 spiders, representing 217 species and 47 families were sampled; Gnaphosidae (39 species), Lycosidae (28 species), Zodariidae (23 species), and Salticidae (22 species) were the most diverse families. These four families represent $57 \%$ of all spiders caught. There were 260 beetle species in the three families, and altogether 14,109 individuals were sampled: 59 carabid, 119 scarabaeid, and 82 tenebrionid species. Scarabaeidae was the most abundant beetle family (9567 individuals), followed by Tenebrionidae (3885 individuals) and Carabidae (657 individuals).

On average, much more beetles (93) than spiders (19) were caught in a sampling unit. Coverage was also higher. Predictably average coverage was also higher for beetles (0.9) compared to the spiders (0.69). However, only slightly more beetle species (9.1) than spider species (7.3). Mean diurnal range in temperature was an important predictor of both beetles and spiders richness which increased with increasing diurnal range (Table 1). Beetle richness was negatively associated with isothermality in the best model (Table 1), while spider richness decreased towards lower latitudes and in association with mixed/other trees. There was a significant relationship between predicted species richness at a sampling unit and the observed species richness for beetles $\left(\mathrm{R}^{2}=0.604, \mathrm{p}<0.001\right.$, Fig. 2$)$ and spiders $\left(\mathrm{R}^{2}=0.56, \mathrm{p}<0.001\right.$, Fig. 2) Fixed effects in the best model for beetle richness explained $52 \%$ of the variance while fixed and random effects explained $80 \%$. Fixed effects in the best model for spider richness explained $28 \%$ of the variance while fixed and random effects explained $58 \%$. Variograms of the residuals of both models were not correlated with distance and suggesting that there was no spatial autocorrelation between sites (Fig. S1).

Models of compositional similarity that included localscale variables (leaf litter, canopy cover, vegetation type and organic content of soil) explained $46 \%$ of the variation compared to $43 \%$ when only broad-scale variables were included. Therefore, including these finer scale variables improved our ability to predict compositional turnover in assemblages. Important local-scale variables were leaf litter, where turnover increased with leaf litter cover (Fig. 3d), and the organic content of the soil (Table 2), which suggests that these act as filters at a finer scale. Leaf litter cover between 50 and $100 \%$ was particularly important in explaining turnover.

However, predictors that summarize aspects of temperature variability dominated both broad and fine-scale models (Table 2), isothermality (Fig. 3a), and mean diurnal range (Fig. 3c). The distribution of deciduous broad-leaved trees was the only land cover variable that was important
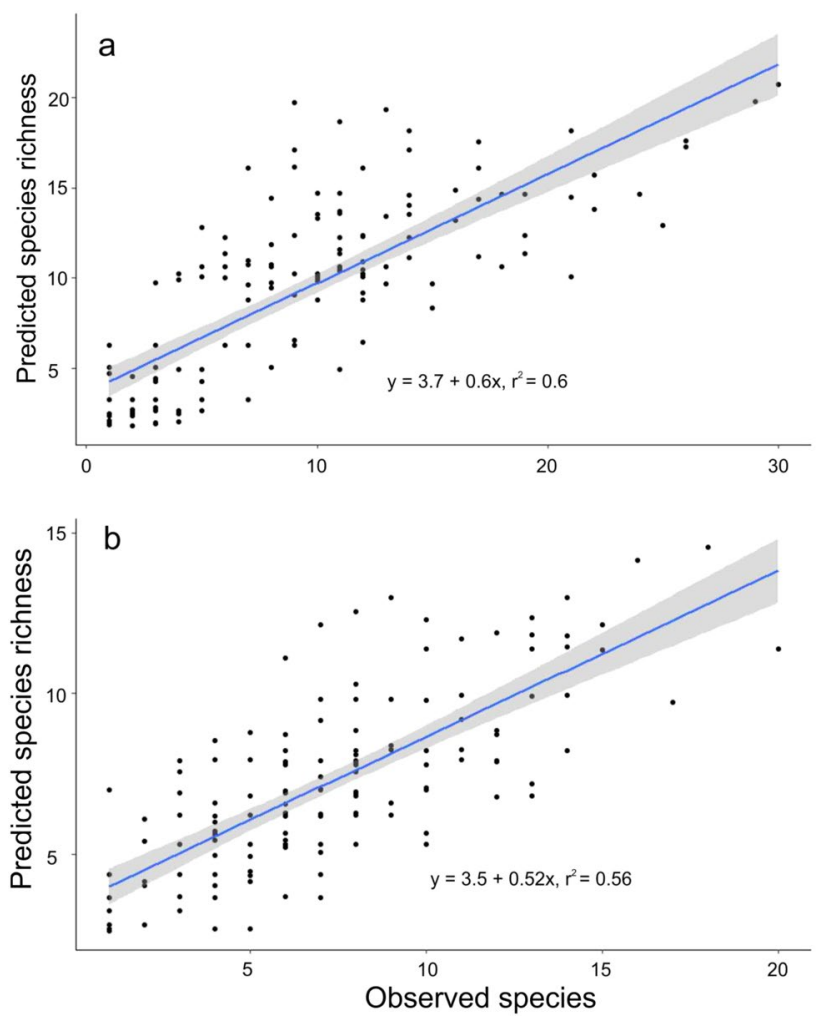

Fig. 2 The relationship between predicted (GLMM) and observed $\mathbf{a}$ beetle and $\mathbf{b}$ spider species richness in the VBR

(Table 2). The contrast between north and southern facing aspects in community composition was also evident, while geographic distance also plays an important role with the rate of turnover being low over short distances and increasing at distances larger than $0.5^{\circ}$ or approximately $55 \mathrm{~km}$ (Table 2; Fig. 3b).

There is a clear east-to-west gradient in compositional turnover across the VBR, but also a north-south gradient and distinct assemblages associated with the mountain (Fig. 4a) and the model does relatively well in predicting observed dissimilarities based on scaled ecological distances. The elbow plot of K-means clustering identified five communities (Fig. 4b). Detailed regional studies on beetle species characterizing these communities is provided in Schoeman et al. (2018, 2019b). Survey coverage were low, averaging at $7 \%(5.7-12)$ of the scaled ecological environments and was particularly low for the lowlands of the eastern parts of the VBR and peaked on the eastern highlands (Fig. 4c).

The current core zones conserve $25 \%$ of the scaled ecological environments (Fig. 5a), this doubles when the existing buffer zones are included (Fig. 5b,e). Adding these buffer zones increases the area covered by the core by less than $50 \%$, but doubles the number of species (Fig. 5f). The core area of the proposed zonation cover 
Table 1 Summary of the best models predicting species richness for beetles and spiders

\begin{tabular}{llll}
\hline Model & $\begin{array}{l}\text { Log likeli- } \\
\text { hood }\end{array}$ & AIC & $\Delta$ AIC
\end{tabular}

\section{Beetles}

Mean diurnal range + isothermality

$\begin{array}{lll}-394.1 & 796.2 \quad 0\end{array}$

Mean diurnal range + isothermality + precipitation seasonality

$-393.9 \quad 797.7$

Best model $\mathrm{S}_{\mathrm{obs}}=\mathrm{e}^{1.99(0.11)+0.41(0.09) \text { mean diurnal range }-0.33(0.09) \text { isothermality }} \cdot \mathrm{R}_{\mathrm{m}}^{2}=0.52, \mathrm{R}_{\mathrm{c}}^{2}=0.8$

Spiders

Mean diurnal range + mixed/other trees

$\begin{array}{lll}-255.8 & 521.5 & 0 \\ -255 & 521.7 & 0.2\end{array}$

Mean diurnal range + latitude + mixed/other trees

$-255$
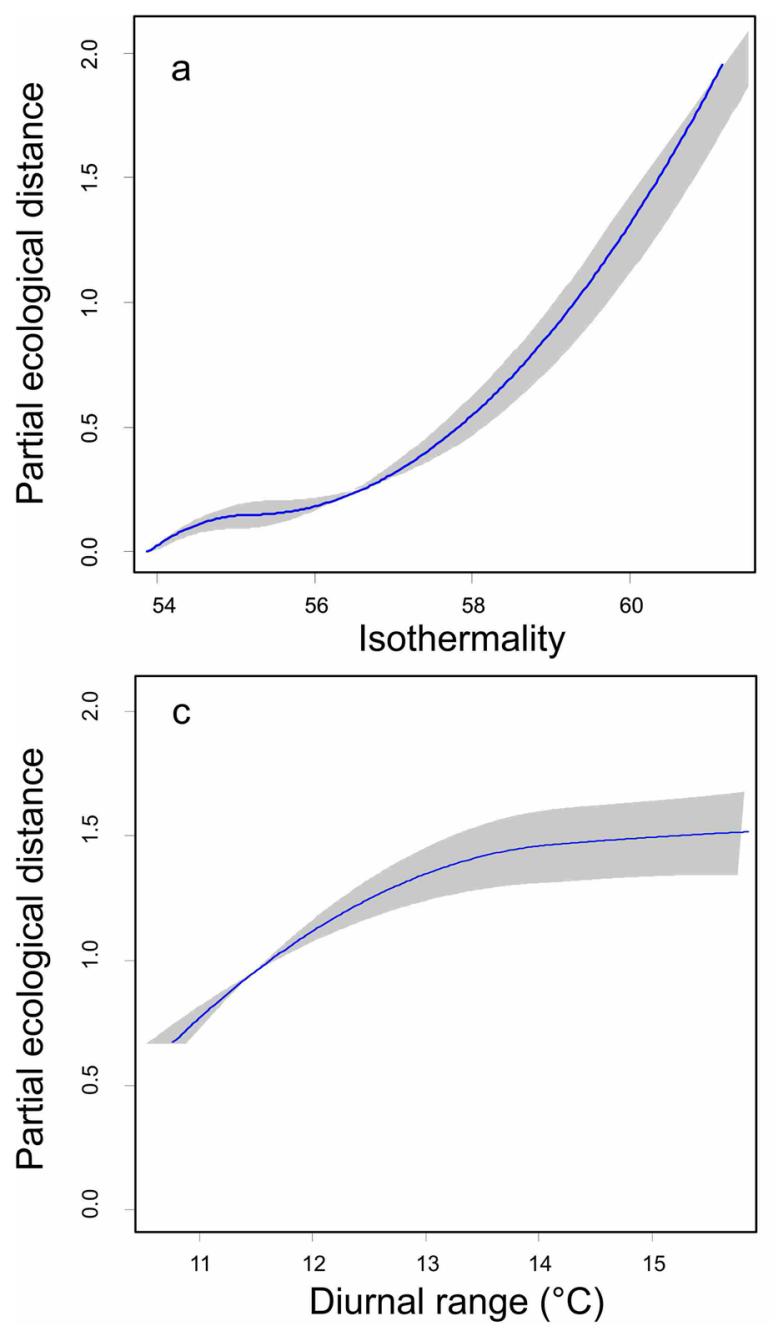

Fig. 3 Generalized dissimilarity model fitted I-splines (partial regression fits) of selected environmental predictors, significantly associated with compositional turnover of spiders and beetles in the VBR. The total $\beta$-diversity explained by a variable is given by the maxi-
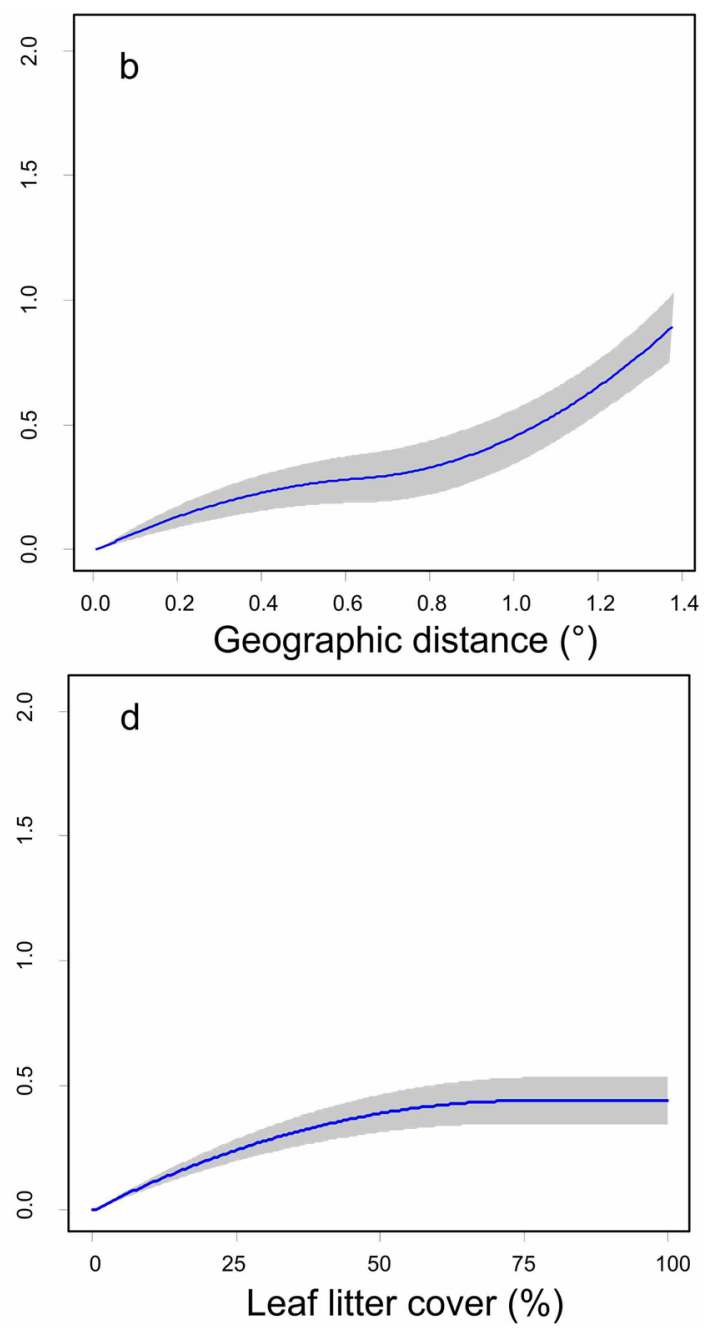

mum height reached by a curve and reflects the total amount of compositional turnover explained by that variable when all other variables held constant. The rate and change of compositional turnover is reflected in the shape of the curve 
Table 2 Significance and importance of variables for VBR beetle and spider $\beta$-diversity based on 50 permutations of the generalized dissimilarity models

\begin{tabular}{llll}
\hline Variable & Scale & Large-scale only & $\begin{array}{l}\text { Large and } \\
\text { fine-scale }\end{array}$ \\
\hline Geographic & Large & $2.2^{*}$ & $1.83^{*}$ \\
Slope & Large & $0.7^{*}$ & $0.46^{*}$ \\
East-West & Large & 0.5 & $0.53^{*}$ \\
North-South & Large & $2.9^{*}$ & $2.38^{*}$ \\
Topographic Position index & Large & 0.2 & 0.18 \\
Mean diurnal range & Large & $5.6^{*}$ & $4.42^{*}$ \\
Isothermality & Large & $9.9^{*}$ & $5.36^{*}$ \\
Precipitation seasonality & Large & $2.7^{*}$ & $2.02^{*}$ \\
Deciduous broadleaf trees & Large & $5.6^{*}$ & $4.81^{*}$ \\
Mixed/other trees & Large & - & - \\
Shrubs & Large & - & - \\
Herbaceous vegetation & Large & 0.03 & - \\
Leaf litter & Fine & NA & $2.25^{*}$ \\
Cannopy cover & Fine & NA & 0.78 \\
Organic content & Fine & NA & $2.17^{*}$ \\
Vegetation complexity & Fine & NA & 0.09 \\
\hline
\end{tabular}

An $\mathrm{n}$-dash indicates variables which explained no model variance $(* \mathrm{p}<0.05)$

$50 \%$ of the VBR but includes $75 \%$ of the scaled ecological environments, while including the proposed buffer zones (Fig. 5d) increases this proportion to almost 100\% (97\%) but cover $75 \%$ of the VBR (Fig. 5f). Similar results were obtained using LEDET's Critical Biodiversity Areas 1 and CBA 2 (Fig. S2).

\section{Discussion}

Compositional turnover of the invertebrates in this study was mainly the result of variability in temperature and vegetation cover (deciduous broadleaved forests). Although local-scale variables increased the amount of variation explained by 24\% (Table 2), the importance of temperature is evident. Future changes in land cover and climate would therefore have important implications for community composition. The fact that temperature co-vary with a range of other variables precludes the identification of any causal relationships, but temperature and vegetation certainly provide some explanatory power within this context. The ability to predict these changes are confounded by the low sample coverage across the biome as invertebrate communities at VBR are largely unknown. Current buffer zones double conservation for a $50 \%$ increase in area, while the proposed buffer zone and that of the gazetted Limpopo conservation plan almost conserved all (100\%) of the ecological environments identified. Provincial conservation efforts complement the proposed zonation.

The most important broad-scale variables affecting the distribution of biodiversity over the region were related to temperature: isothermality and mean diurnal range. These are important bioclimatic predictors related to species physiology, showing that temperature fluctuations and extremes are key to assembling species over larger areas (O'Donnell and Ignizio 2012). In our analysis these co-varied with elevation and precipitation, acting as appropriate proxies (Gaston 2000; Willig et al. 2003). Deciduous broad-leaved trees were the only important large-scale land cover variable, linking plant functional traits with herbivory (Njovu et al. 2019).

Geographic distance is known to have an important impact on community assembly (Schoeman and Foord 2012). Soininen (2016) showed that dispersal ability is limited for spiders over large areas. This may be explained by highly localized availability of resources (Wise 2006; Saxer et al. 2009) with the resultant observation of distinct communities. The evolutionary history of invertebrate distribution over distance is an acknowledged phenomenon, although it cannot be isolated from the effect of habitat and vegetation type (Qian and Ricklefs 2012). Here we do not attempt to disentangle the relationship between geographic distance and environmental distance. Carvalho et al. (2011) found that broad-scale environmental gradients drove Mediterranean spider species richness. In general, large-scale selection of conservation units is effective in conserving regional biodiversity (Rouget 2003; Schaffers et al. 2008; Ramos et al. 2018).

Fine scale variables, such as leaf litter and organic content, were also important drivers especially for invertebrates which are small and often associated with micro-habitats. Barton et al. (2011) found that beetles in grassy Australian woodland were more strongly affected by micro-habitat elements such as logs than macro-habitat elements. MacLeod et al. (2004) have also shown that fine scale refuges and shelters are essential for the maintenance of carabid assemblages. Similarly, Barton et al. (2010) found that two different species of co-occurring eucalyptus supported different assemblages of litter-dwelling beetles. Some of the species in the VBR are very dependent on micro-scale elements especially in forests. For instance, a carabid endemic from afro-montane forests, Wahlbergiana alternans, is found predominantly under rocks in areas of densely compacted leaf litter. The importance of leaf litter could be related to the sampling method used in this study. Pitfall traps capture more active invertebrates and not sample less active litter dwelling species. such as Collembola and Staphylinidae, which are normally abundant faunas associated with leaf litter (Gerlach et al. 2013; Janion-Scheepers et al. 2016). A study by Maudsley et al. (2002) found high numbers of Carabidae in leaf litter in hedgerows in England. Speciose 

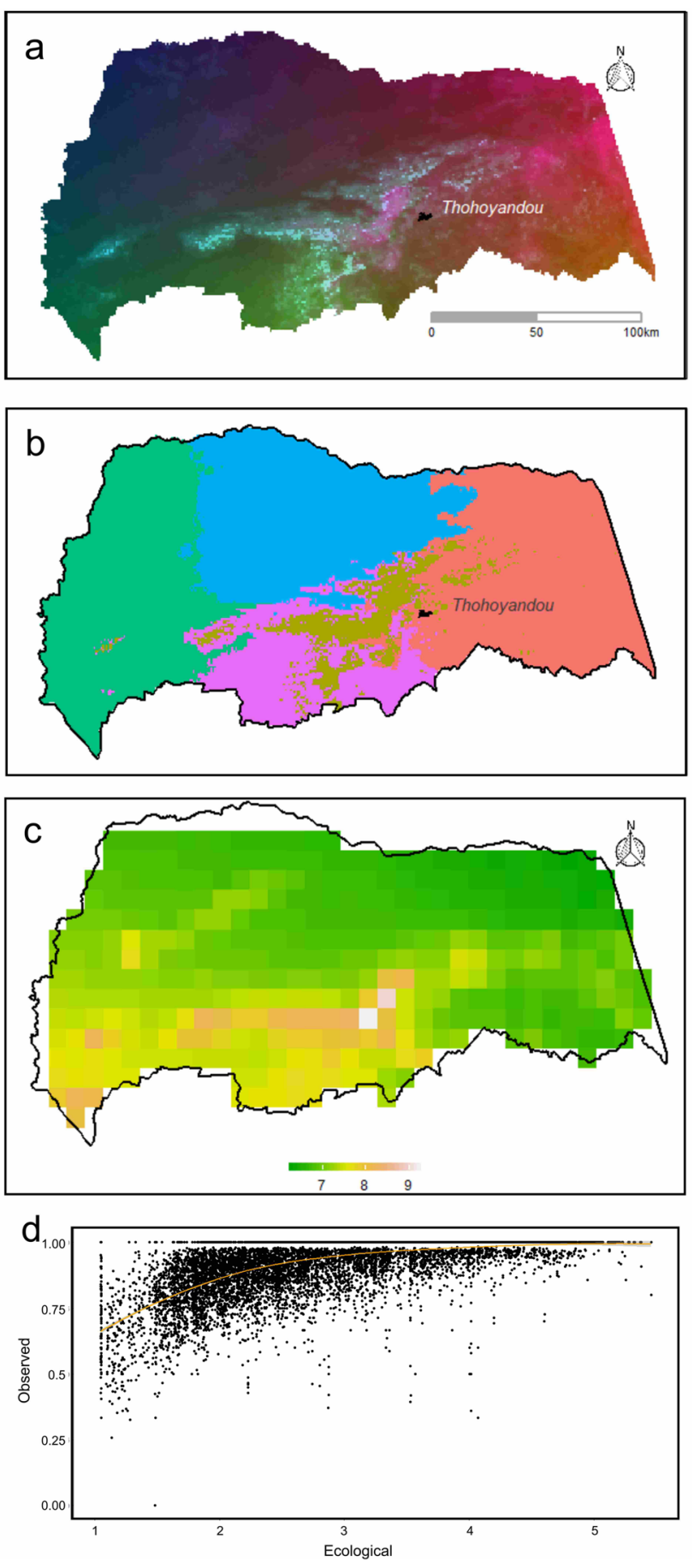

Fig. 4 a Patterns of compositional turnover across the VBR as illustrated in colour, $\mathbf{b}$ five groups of communities identified using k-means clustering, with each colour indicating a distinct community (c) sample coverage across the VBR (light brown-higher coverage, green-lower coverage) and d relationship between observed compositional dissimilarity of invertebrate communities and the predicted ecological distance based on linear predictors of regression equation in GDM carabid taxa associated with leaf litter and recorded from the region (Harpalinae, Chleiniinae, and Pterostichinae) were very poorly represented in our samples.

We found a strong east-to-west gradient in richness among Tenebrionidae, observing that the decline in richness towards the east reflected movement away from the southwest African centre of tenebrionid diversity. However, the Soutpansberg harbours a unique community. The change in composition may be driven by a decrease in temperature, which lowers the activity of ectotherms at higher elevations, reduction in possible habitat (e.g., mountain tops), and a decrease in resource abundance associated with reduced habitat size (Classen et al. 2015). Although richness often decreases with elevation, there is also a definite increase in complementarity with elevation, so that sites on the mountain are distinct, harbouring a considerable number of endemics (Munyai and Foord 2015). Assemblages north and south of the Soutpanberg mountain are also distinct, emphasizing the importance of beta diversity studies that focus on complimentarity.

In the current zonation, topographically complex sites such as the western Soutpansberg and Blouberg were included in the core and buffer zones as they have low human population density on unproductive quartzitic derived soils (Hahn 2018). These two mountains can also represent old, climatically buffered, infertile landscapes (OCBIL) within the VBR (Hopper 2009). Like the Cape Floristic Region, the above-mentioned mountains are characterized by high levels of diversity and endemism. The narrow distribution ranges and limited dispersal capabilities of taxa coupled with strong environmental gradients and relative climatic stability on these mountains could account for the high richness patterns we observed in the core areas. For instance, species of the darkling beetle Anaxius (Kamiński and Schoeman 2018) are limited to elevations higher than 900 m.a.s.l. across the bushveld of southern Africa, with endemic species limited to particular ranges. Most rare and endemic species of spiders are also mainly found in the Soutpansberg and Blouberg and their surrounding foothills (Foord et al. 2002; Foord et al. 2019).

We found that the proposed zonation which encompasses significantly large tracts of land conserves almost all species. The coverage results highlight the importance of large conservation areas (e.g., Kruger National Park) in regional conservation efforts. We found that the KNP's conservation footprint extends well beyond its border in terms of ecological environments conserved. However, both current and proposed zonation reflect the priorities of humans with infertile arid land (the OCBILS) comprising most of the core areas and buffer zones (Hopper et al. 2016).

Both the Biosphere and provincial zonation effectively represented invertebrate diversity in the VBR and suggest that 

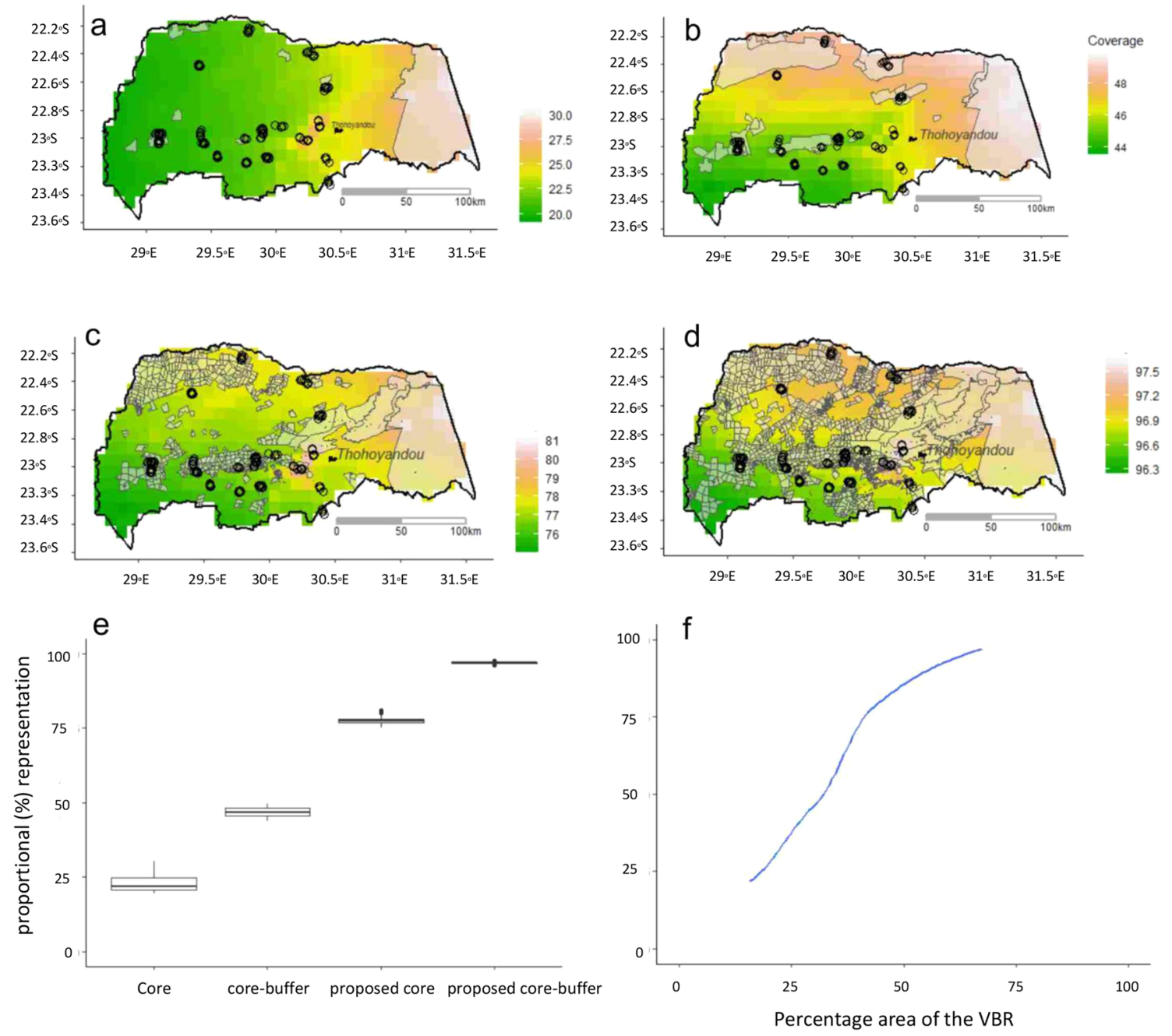

Fig. 5 Proportional (\%) representation of ecological environments in the (a) current core, (b) current core and buffer, (c) proposed core, and (d) proposed core and buffer zones of the Vhembe Biosphere

Reserve. Boxplot (e) of changes in proportional representation of ecological environments for these four scenarios and the (f) percentage area of the VBR falling within these four scenarios

planning based on vertebrates and plants might be successful in conserving invertebrates (Mittermeier et al. 2011). However, the current zonation only represents $50 \%$ of that diversity and it assumes that real world land use reflects that of the planned zonation. Although large scale covariates drive invertebrate distribution, local-scale processes played a significant role in maintaining invertebrate diversity in those areas identified as core and buffer zones. Broader scale changes in climate could be mitigated by focusing on microhabitats and microclimates at smaller scales, managing for fine-scale covariates (e.g., leaving $\operatorname{logs}$ in the veld, simulating natural disturbance regimes). Providing suitable microhabitats could allow for behavioural rescue (Scheffers et al. 2014). Rewilding the proposed core areas by reintroducing ungulate browsers will also help stay bush encroachment and natural trampling optimizing epigaic faunal diversity (Pryke et al. 2016). Buffer zones in this study were highly complementary and would allow for an almost complete

coverage of spider and beetle ecological environments. However, it assumes that land use activities falls within those described for each of the zonation categories.

\section{Appendix}

Map showing (a) localities referred to in text including the Soutpansberg mountain range and the Limpopo Valley, and (b) sites (black dots) within vegetation units (illustrated in different colours) in the Vhembe Biosphere Reserve (VBR), Limpopo Province, South Africa. Makhado Sweet Bushveld (3 sites), Soutpansberg Summit Sourveld (4 sites), Northern Mistbelt Forest (4 sites), Roodeberg Bushveld (2 sites), Soutpansberg Mountain Bushveld (4 sites), Musina Mopane Bushveld (2 sites), and Limpopo Ridge Bushveld (1 site) 


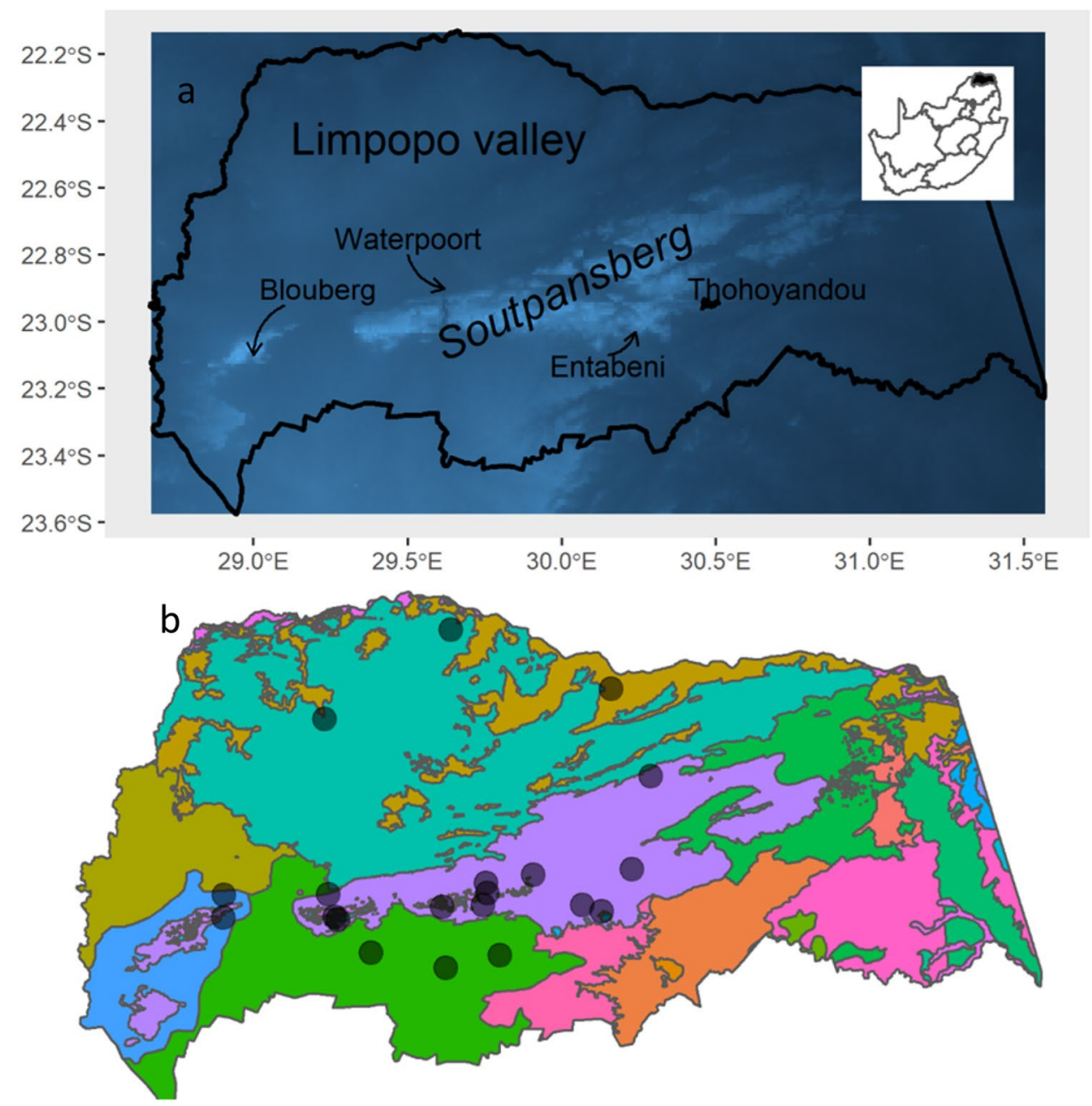

Supplementary Information The online version contains supplementary material available at https://doi.org/10.1007/s10841-021-00326-7.

Acknowledgements We are particularly grateful to all landowners who allowed us to work on their properties. We acknowledge the SARChI Chair for Biodiversity and Change and Directorate for Research and Research Innovation at the University of Venda for logistic and financial support. We are very grateful to Ansie Dippenaar-Schoeman, Ruth Muller and Adrian Davis for species identification. We thank Michelle Hamer, Dawn Corey Toussaint and Danie Booyens for providing insights and support during this study.

\section{Declarations}

Ethical approval Specimens were collected on permit no. CPM-00500005, provided by Limpopo Department of Economic Development, Environment and Tourism. The research leading to these results received funding from the University of Venda Research and Publications Committee under grant no P109. The authors declare they have no financial interests.

\section{References}

Barton PS, Manning AD, Gibb H, Lindenmayer DB, Cunningham SA (2010) Fine-scale heterogeneity in beetle assemblages under co-occurring Eucalyptus in the same subgenus. J Biogeogr 37(10):1927-1937. https://doi.org/https://onlinelibrary.wiley. com/doi/full/https://doi.org/10.1111/j.1365-2699.2010.02349.x

Barton PS, Manning AD, Gibb H, Wood JT, Lindenmayer DB, Cunningham SA (2011) Experimental reduction of native vertebrate grazing and addition of logs benefit beetle diversity at multiple scales. J Appl Ecol 48(4): 943-951. https://doi.org/https://besjo urnals.onlinelibrary.wiley.com/doi/https://doi.org/10.1111/j. 1365-2664.2011.01994.x

Bellard C, Bertelsmeier C, Leadley P, Thuiller W, Courchamp F (2012) Impacts of climate change on the future of biodiversity. Ecol lett 15(4):365-377. https://doi.org/https://onlinelibr ary.wiley.com/doi/https://doi.org/10.1111/j.1461-0248.2011. 01736.x

Burnham KP, Anderson DR (2004) Multimodel inference: understanding AIC and BIC model selection. Social Methods Res 37:261-304. https://doi.org/10.1177/0049124104268644

Cardoso P, Barton PS, Birkhofer K, Chichorro F, Deacon C, Fartmann T, Fukushima CS, Gaigher R, Habel JC, Hallmann CA, Hill MJ, Hochkirch A, Kwak ML, Mammola S et al (2020) 
Scientists' warning to humanity on insect extinctions. Biol Conserv 242:108426. https://doi.org/10.1016/j.biocon.2020.108426

Carvalho JC, Cardoso P, Crespo LC, Henriques S, Carvalho R, Gomes P (2011) Determinants of beta diversity of spiders in coastal dunes along a gradient of mediterraneity. Divers Distrib 17(2): 225-234. https://doi.org/https://onlinelibrary.wiley.com/ doi/full/10.1111/j.1472-4642.2010.00731.x

Chao A, Jost L (2012) Coverage-based rarefaction and extrapolation: standardizing samples by completeness rather than size. Ecology 93(12):2533-2547. https://doi.org/10.1890/11-1952.1

Classen AT, Sundqvist MK, Henning JA, Newman GS, Moore JA, Cregger MA, Moorhead LC, Patterson CM (2015) Direct and indirect effects of climate change on soil microbial and soil microbial-plant interactions: what lies ahead? Ecosphere 6(8):1-21. https://doi.org/10.1890/ES15-00217.1

Constant NL, Bell S (2017) Governance, participation and local perceptions of protected areas: unwinding traumatic nature in the Blouberg Mountain Range. Environ Values 26(5):539-559. https://doi.org/10.3197/096327117X15002190708100

De Boeck P, Bakker M, Zwitser R, Nivard M, Hofman A, Tuerlinckx F, Partchev I (2011) The estimation of item response models with the lmer function from the lme4 package in R. J Stat Softw 39(12):1-28

Desmet PG, Holness S, Skowno A, Egan VT (2013) Limpopo conservation plan. Contract Number LEDET/2216/2012. Limpopo Department of Economic Development, Environment and Tourism (LEDET). https://doi.org/https://conservationcorridor.org/ cpb/Desmet_et_al_2013.pdf. Accessed 11 May 2021

Díaz S, Settele J, Brondízio E, Ngo H, Guèze M, Agard J, Arneth A, Balvanera P, Brauman K, Butchart S, Chan K (2020) Summary for policymakers of the global assessment report on biodiversity and ecosystem services of the Intergovernmental Science-Policy Platform on Biodiversity and Ecosystem Services. https:// doi.org/https://uwe-repository.worktribe.com/output/1493508. Accessed 10 May 2021

Dippenaar-Schoeman A, Van den Berg A, Lyle R, Haddad C, Foord S, Lotz L (2012) Die diversiteit van Suid-Afrikaanse spinnekoppe (Arachnida: Araneae): Dokumentering van 'n nasionale opname., Suid-Afrikaanse Tydskrif vir Natuurwetenskap en Tegnologie 32(1): 1-7. https://doi.org/https://journals.co.za/ doi/abs/https://doi.org/10.4102/satnt.v32i1.375

Dippenaar-Schoeman AS (2014) Field guide to the spiders of South Africa. Lapa, Pretoria

Ferrier S, ManionG, Elith J, Richardson K (2007) Using generalized dissimilarity modelling to analyse and predict patterns of beta diversity in regional biodiversity assessment. Divers Distrib 13:252-264

Ferrier S, Powell GV, Richardson KS, Manion G, Overton JM, Allnutt TF, Cameron SE, Mantle K, Burgess ND, Faith DP, Lamoreux JF (2004) Mapping more of terrestrial biodiversity for global conservation assessment. Bioscience 54(12):1101-1109. https://doi.org/ https://onlinelibrary.wiley.com/doi/full/https://doi.org/10.1111/j. 1472-4642.2007.00341.x

Fick SE, Hijmans RJ (2017) WorldClim 2: new 1-km spatial resolution climate surfaces for global land areas. Int J Climatol 37(12):4302_ 4315. https://doi.org/10.1002/joc.5086

Fitzpatrick M, Lisk M (2016) Using the R package gdm to analyse and map biodiversity patterns. https://doi.org/https://cran.r-proje ct.org/web/packages/gdm/vignettes/gdmVignette.pdf. Accessed 1 May 2021

Foord S, Dippenaar-Schoeman AS, Haddad CR, Schoeman C, Hahn N, Lyle R (2019) Spider checklist for the Blouberg, in the Vhembe Biosphere Reserve, South Africa. Afr Biodivers Conserv 49(1):113. https://doi.org/10.4102/abc.v49i1.2455

Foord SH, Dippenaar-Schoeman AS (2016) The effect of elevation and time on mountain spider diversity: a view of two aspects in the Cederberg mountains of South Africa. J Biogeogr 43(12): 2354-2365. https://doi.org/https://onlinelibrary.wiley.com/doi/ full/https://doi.org/10.1111/jbi.12817

Foord SH, Dippenaar-Schoeman AS, Van der Merwe M (2002) A check list of the spider fauna of the Western Soutpansberg, South Africa (Arachnida: Araneae). Koedoe 45(2):35-43. https://doi. org/10.4102/koedoe.v45i2.25

Foord SH, Gelebe V, Prendini L (2015) Effects of aspect and altitude on scorpion diversity along an environmental gradient in the Soutpansberg, South Africa. J Arid Environ 113:114-120. https://doi. org/10.1016/j.jaridenv.2014.10.006

Foord SH, Dippenaar-Schoeman AS, Haddad CR, Lyle R, Lotz LN, Sethusa T, Raimondo D (2020) The South African National Red List of spiders: patterns, threats, and conservation. J Arachnol 48(2):110-118. https://doi.org/10.4102/koedoe.v60i1.1486

Fox R (2013) The decline of moths in Great Britain: a review of possible causes. Insect Conserv Divers 6(1):5-19. https://doi.org/10. 1111/j.1752-4598.2012.00186.x

Gaigher R, Samways MJ (2014) Landscape mosaic attributes for maintaining ground-living spider diversity in a biodiversity hotspot. Insect Conserv Divers 7:470-479. https://doi.org/10.1111/icad. 12070

Gaston KJ (2000) Global patterns in biodiversity. Nature 405(6783):220-227. https://doi.org/https://www.nature.com/artic les/35012228

Gering JC, Crist TO (2002) The alpha-beta-regional relationship: providing new insights into local-regional patterns of species richness and scale dependence of diversity components. Ecol Lett 5(3):433-444. https://doi.org/10.1046/j.1461-0248.2002.00335.x

Gerlach J, Samways M, Pryke J (2013) Terrestrial invertebrates as bioindicators: an overview of available taxonomic groups. J Insect Conserv 17(4): 831-850. https://doi.org/https://link.springer.com/ article/10.1007/s10841-013-9565-9

Gough L, Grace JB, Taylor KL (1994) The Relationship between Species Richness and Community Biomass: The Importance of Environmental Variables. Oikos 70(2):271-279. https://doi.org/ $10.2307 / 3545638$

Gove AD, Majer JD, Rico-Gray V (2005) Methods for conservation outside of formal reserve systems: The case of ants in the seasonally dry tropics of Veracruz. Mexico Biol Conserv 126(3):328338. https://doi.org/10.1016/j.biocon.2005.06.008

Haddad CR (2009) Vendaphaea, a new dark sac spider genus apparently endemic to the Soutpansberg Mountains, South Africa (Araneae: Corinnidae). Afr Invertebr 50(2):269-278. https://doi.org/ 10.5733/afin.050.0204

Hahn N (2017) Endemic flora of the Soutpansberg, Blouberg and Makgabeng. S Afr J Bot 113:324-336. https://doi.org/10.1016/j.sajb. 2017.09.006

Hahn N (2018) An historic account of the extinct high rainfall grasslands of the Soutpansberg, South Africa. Trans R Soc S Afr 73(1):20-32. https://doi.org/10.1080/0035919X.2017.1346528

Hallmann CA, Sorg M, Jongejans E, Siepel H, Hofland N, Schwan H, Stenmans W, Müller A, Sumser H, Hörren T, Goulson D (2017) More than $75 \%$ decline over 27 years in total flying insect biomass in protected areas. PLoS ONE. https://doi.org/10.1371/journal. pone. 0185809

Hopper SD (2009) OCBIL theory: towards an integrated understanding of the evolution, ecology and conservation of biodiversity on old, climatically buffered, infertile landscapes. Plant Soil 322:49-86. https://doi.org/10.1007/s11104-009-0068-0

Hopper SD, Silveira FA, Fiedler PL (2016) Biodiversity hotspots and Ocbil theory. Plant Soil 403(1-2):167-216. https://doi.org/10. 1007/s11104-015-2764-2

Hutcheson J (1990) Characterization of terrestrial insect communities using quantified, Malaise-trapped Coleoptera. Ecol Entomol 15:143-151. https://doi.org/10.1111/j.1365-2311.1990.tb00795.x 
Ishwaran N, Persic A, Tri NH (2008) Concept and practice: the case of UNESCO biosphere reserves. Int J Environ Sci Dev 7(2):118-131. https://doi.org/10.1504/IJESD.2008.018358

Janion-Scheepers C, Measey J, Braschler B, Chown SL, Coetzee L, Colville JF, Dames J, Daviesh AB, Davies SJ, Davis ALV, Dippenaar-Schoeman AS, Duffy GA, Fourie D, Griffiths C, Haddad CR, Hamer M, Herbert DG, Hugo-Coetzee EA, Jacobs A, Jacobs K, van Rensburg CJ, Lamania A, Lotze LN, vdM Louw S, Lyle R, Malan AP, Marais M, Neethling JA, Nxele TC, Pliskop DJ, Prendini L, Rink AN, Swart A, Theron P, Truter M, Ueckermann E, Uys VM, Villet MH, Willows-Munro S, Wilson JRU (2016) Soil biota in a megadiverse country: Current knowledge and future research directions in South Africa. Pedobiologia 59(3):129-174. https://doi.org/10.1016/j.pedobi.2016.03.004

Kati V, Devillers P, Dufrêne M, Legakis A, Vokou D, Lebrun P (2004) Hotspots, complementarity or representativeness? Designing optimal small-scale reserves for biodiversity conservation. Biol Conserv 120(4):471-480. https://doi.org/10.1016/j.biocon.2004. 03.020

Kamiński MJ, Schoeman CS (2018) Taxonomic revision of a darkling beetle genus Anaxius (Tenebrionidae: Pedinini: Helopinina). Zootaxa 4455(3):471-485. https://doi.org/10.11646/zootaxa. 4455.3.4

Kaufman L, Rousseeuw PJ (2009) Finding groups in data: an introduction to cluster analysis. Wiley, New York

Koleff P, Gaston KJ, Lennon JJ (2003) Measuring beta diversity for presence-absence data. J Anim Ecol 72:367-382. https://doi.org/ 10.1046/j.1365-2656.2003.00710.x

Kremen C, Merenlender AM (2018) Landscapes that work for biodiversity and people. Science. https://doi.org/10.1126/science.aau6020

Leather SR (2017) "Ecological Armageddon"-more evidence for the drastic decline in insect numbers. Ann Appl Biol 172(1):1-3. https://doi.org/10.1111/aab.12410

Lombard AT, Cowling RM, Pressey RL, Rebelo AG (2003) Effectiveness of land classes as surrogates for species in conservation planning for the Cape Floristic Region. Biol Conserv 112(1-2):45-62. https://doi.org/10.1016/S0006-3207(02)00422-6

MacLeod A, Wratten SD, Sotherton NW, Thomas MB (2004) 'Beetle banks' as refuges for beneficial arthropods in farmland: long-term changes in predator communities and habitat. Agric For Entomol 6(2):147-154. https://doi.org/10.1111/j.1461-9563.2004.00215.x

Mammola S, Cardoso P, Angyal D, Balázs G, Blick T, Brustel H, Carter J, Ćurčić S, Danflous S, Dányi L, Déjean S (2019) Local-versus broad-scale environmental drivers of continental $\beta$-diversity patterns in subterranean spider communities across Europe. Proc R Soc B. https://doi.org/10.1098/rspb.2019.1579

Maudsley M, Seeley B, Lewis O (2002) Spatial distribution patterns of predatory arthropods within an English hedgerow in early winter in relation to habitat variables. Agric Ecosyst Environ 89(1-2):77-89. https://doi.org/10.1016/S0167-8809(01)00320-6

Mittermeier RA, Turner WR, Larsen FW, Brooks TM, Gascon C (2011) Global biodiversity conservation: the critical role of hotspots. In: Zachos FE, Habel JC (eds) Biodiversity hotspots: distribution and protection of conservation priority areas. Springer, Berlin

Modiba RV, Joseph GS, Seymour CL, Fouché P, Foord SH (2017) Restoration of riparian systems through clearing of invasive plant species improves functional diversity of Odonate assemblages. Biol Conserv 214:46-54. https://doi.org/10.1016/j.biocon.2017.07.031

Mucina L, Rutherford MC (2006) The vegetation of South Africa, Lesotho and Swaziland. Strelitzia 19. South African National Biodiversity Institute, Pretoria

Munyai TC, Foord SH (2015) An inventory of epigeal ants of the western Soutpansberg Mountain Range, South Africa. Koedoe 57(1):1-12. https://doi.org/10.4102/koedoe.v57i1.1244

Nakagawa S, Schielzeth H (2010) Repeatability for Gaussian and non-Gaussian data: a practical guide for biologists. Biol Rev
85(4):935-956. https://doi.org/10.1111/j.1469-185X.2010. 00141.x

Njovu HK, Peters MK, Schellenberger Costa D, Brandl R, Kleyer M, Steffan-Dewenter I (2019) Leaf traits mediate changes in invertebrate herbivory along broad environmental gradients on Mt. Kilimanjaro, Tanzania. J Anim Ecol 88(11):1777-1788. https:// doi.org/10.1111/1365-2656.13058

Nyffeler M, Birkhofer K (2017) An estimated 400-800 million tons of prey are annually killed by the global spider community. Sci Nat 104:30. https://doi.org/10.1007/s00114-017-1440-1

O'Donnell MS, Ignizio DA (2012) Bioclimatic predictors for supporting ecological applications in the conterminous United States. US Geological Survey Data Series 691(10): 4-9. https://doi.org/ https://pubs.usgs.gov/ds/691/. Accessed 1 May 2021

Oliver I, Beattie AJ, York A (1998) Spatial fidelity of plant, vertebrate, and invertebrate assemblages in multiple-use forest in eastern Australia. Conserv Biol 12(4):822-835. https://doi.org/10.1111/j. 1523-1739.1998.97075.x

Pennifold MG, Williams KJ, Pinder AM, Harwood TD, Manion G, Ferrier S (2017) Whole-landscape modelling of compositional turnover in aquatic invertebrates informs conservation gap analysis: An example from south-western Australia. Freshw Biol 62:1359-1376. https://doi.org/10.1111/fwb.12949

Picker M, Griffiths C, Weaving A (2004) Field Guide to Insects of Southern Africa. Struik, Cape Town

Pool-Stanvliet R (2013) A history of the UNESCO Man and the Biosphere Programme in South Africa. S Afr J Sci 109(9-10):01-06. https://doi.org/10.1590/sajs.2013/a0035

Pryke JS, Roets F, Samways MJ (2016) Wild herbivore grazing enhances insect diversity over livestock grazing in an African grassland system. PLoS ONE. https://doi.org/10.1371/journal. pone. 0164198

Qian H, Ricklefs RE (2012) Disentangling the effects of geographic distance and environmental dissimilarity on global patterns of species turnover. Glob Ecol Biogeogr 21(3):341-351. https://doi. org/10.1111/j.1466-8238.2011.00672.x

R Core Team (2021) R: A language and environment for statistical computing. R Foundation for Statistical Computing, Vienna, Austria. https://doi.org/http://www.R-project.org/. Accessed 1 May 2021

Ramos CS, Isabel Bellocq M, Paris CI, Filloy J (2018) Environmental drivers of ant species richness and composition across the Argentine Pampas grassland. Austral Ecol 43(4):424-434. https://doi. org/10.1111/aec.12579

Reyers B, Jaarsveld AV, Krüger M (2000) Complementarity as a biodiversity indicator strategy. Proc R Soc Lond [Biol] 267(1442):505513. https://doi.org/10.1098/rspb.2000.1029

Rouget M (2003) Measuring conservation value at fine and broad scales: implications for a diverse and fragmented region, the Agulhas Plain. Biol Conserv 112(1-2):217-232. https://doi.org/ 10.1016/S0006-3207(02)00415-9

Samways MJ, McGeoch MA, New TR (2010) Insect conservation: a handbook of approaches and methods. Oxford University Press, Oxford

Samways MJ, Barton PS, Birkhofer K, Chichorro F, Deacon C, Fartmann T, Fukushima CS, Gaigher R, Habel JC, Hallmann CA, Hill MJ et al (2020) Solutions for humanity on how to conserve insects. Biol Conserv 242:108427. https://doi.org/10.1016/j.biocon.2020.108427

Sánchez-Bayo F, Wyckhuys KA (2019) Worldwide decline of the entomofauna: A review of its drivers. Biol Conserv 232:8-27. https:// doi.org/10.1016/j.biocon.2019.01.020

Sauberer N, Zulka KP, Abensperg-Traun M, Berg HM, Bieringer G, Milasowszky N, Moser D, Plutzar C, Pollheimer M, Storch C, Tröstl R (2004) Surrogate taxa for biodiversity in agricultural 
landscapes of eastern Austria. Biol Conserv 117(2):181-190. https://doi.org/10.1016/S0006-3207(03)00291-X

Saxer G, Doebeli M, Travisano M (2009) Spatial structure leads to ecological breakdown and loss of diversity. Proc R Soc Lond [Biol] 276:2065-2070. https://doi.org/10.1098/rspb.2008.1827

Schaffers AP, Raemakers IP, Sýkora KV, Ter Braak CJ (2008) Arthropod assemblages are best predicted by plant species composition. Ecology 89(3):782-794. https://doi.org/10.1890/07-0361.1

Scheffers BR, Evans TA, Williams SE, Edwards DP (2014) Microhabitats in the tropics buffer temperature in a globally coherent manner. Biol Lett 10(12):20140819. https://doi.org/10.1098/rsbl. 2014.0819

Schoeman CS, Samways MJ (2011) Synergisms between Alien Trees and the Argentine Ant on Indigenous Ant Species in the Cape Floristic Region, South Africa. Afr Entomol 19(1):96-105. https:// doi.org/10.4001/003.019.0117

Schoeman CS, Foord SH (2012) Deciding on an appropriate scale for conservation activities: partitioning alpha and beta ant diversity in North-West Province, South Africa (Formicidae: Hymenoptera). Trans R Soc S Afr 67(1):1-10. https://doi.org/10.1080/0035919X. 2011.641690

Schoeman CS, Tshililo P, Foord SH, Hamer M (2018) Annotated checklist of Carabidae (Insecta: Coleoptera) of the Vhembe Biosphere Reserve, South Africa. https://doi.org/10.13140/RG.2.2. 33610.06089

Schoeman CS, Hahn N, Hamer M, Foord SH (2019a) Regional invertebrate cross-and within-taxon surrogacy are scale and taxon dependent. Trans R Soc S Afr 75(1):23-32. https://doi.org/10. 1080/0035919X.2019.1658656

Schoeman CS, Cory Toussaint D, Tshililo P, Foord SH, Hamer M (2019b) Darkling beetles of the bushveld: an annotated checklist of the Tenebrionidae of the Vhembe Biosphere Reserve, South Africa (Coleoptera). https://doi.org/10.13140/RG.2.2.29054.33604

Schönhofer AL (2008) On harvestmen from the Soutpansberg, South Africa, with description of a new species of Monomontia (Arachnida: Opiliones). Afr Invertebr 49(2):109-126. https://doi.org/10. 5733/afin.049.0206

Sieh T, Ma K, Chao A (2014) iNEXT: iNterpolation and EXTrapolation for species diversity. R package version 2.0. https://doi.org/ http://chao.stat.nthu.edu.tw/blog/software-download. Accessed 1 May 2021

Soininen J (2016) Spatial structure in ecological communities-a quantitative analysis. Oikos 125(2):160-166. https://doi.org/10.1111/ oik.02241

Su JC, Debinski DM, Jakubauskas ME, Kindscher K (2004) Beyond species richness: community similarity as a measure of crosstaxon congruence for coarse-filter conservation. Conserv Biol 18(1):167-173. https://doi.org/10.1111/j.1523-1739.2004.00337.x

Tuanmu MN, Jetz W (2014) A global 1-km consensus land-cover product for biodiversity and ecosystem modelling. Glob Ecol Biogeogr 23(9):1031-1045. https://doi.org/10.1111/geb.12182

UNESCO (2021) Biosphere Reserves in Africa. https://doi.org/https:// en.unesco.org/biosphere/africa/. Accessed 1 May 2021

Van Schalkwyk J, Pryke JS, Samways MJ, Gaigher R (2019) Complementary and protection value of a Biosphere Reserve buffer zone for increasing local representativeness of ground-living arthropods. Biol Conserv 239:108292. https://doi.org/10.1016/j.biocon. 2019.108292

Vhembe DM (2017) Vhembe District Bioregional Plan. Compiled by: Limpopo Department of Economic Development, Environment and Tourism (LEDET). http://www.nuleafsa.co.za/wp-content/ uploads/2018/01/Vhembe-Bioregional-Plan_rev4_Dec-2017_ name-changes.pdf. Accessed 1 May 2021

Willig MR, Kaufman DM, Stevens RD (2003) Latitudinal gradients of biodiversity: pattern, process, scale, and synthesis. Annu Rev Ecol Evol Syst 34(1):273-309. https://doi.org/10.1146/annurev. ecolsys.34.012103.144032

Wise DH (2006) Cannibalism, food limitation, intraspecific competition, and the regulation of spider populations. Annu Rev Entomol 51:441-465. https://doi.org/10.1146/annurev.ento.51.110104. 150947

Woodroffe R, Ginsberg JR (1998) Edge effects and the extinction of populations inside protected areas. Science 280(5372):2126-2128. https://doi.org/10.1126/science.280.5372.2126

Publisher's Note Springer Nature remains neutral with regard to jurisdictional claims in published maps and institutional affiliations. 